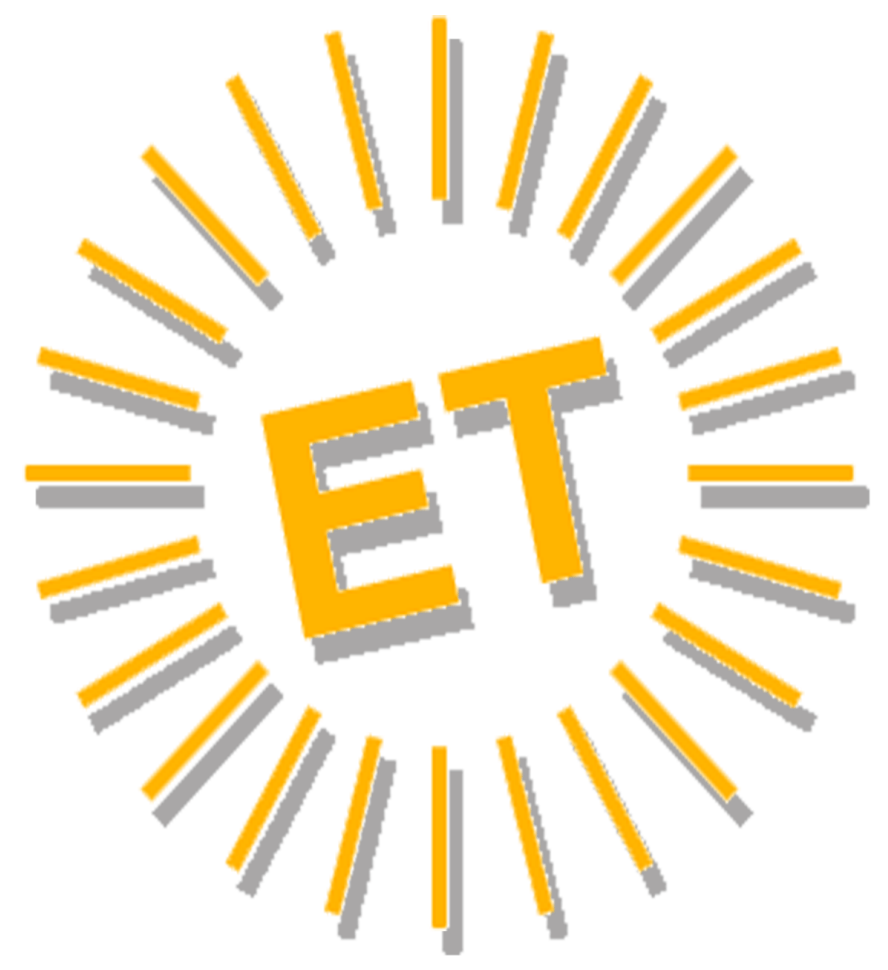




\section{Editorial Team}

Editor in Chief

Alfonso Vargas-Sánchez, University of Huelva, Spain

\section{Associate Editor}

T.C. Huan, National Chiayi University, Taiwan

\section{Books Review Editor}

Brendan Paddison, York St. John University, United Kingdom

\section{Secretariat}

Elena García de Soto, University of Huelva, Spain

Cinta Borrero-Domínguez, University of Huelva, Spain

\section{Style reviewer and text editor}

Anestis Fotiadis, I-SHOU University, Taiwan, Province of China

\section{Editorial Board}

José Manuel Alcaraz, Murdoch University, Australia Mario Castellanos-Verdugo, University of Seville, Spain José Antonio Fraiz-Brea, University of Vigo, Spain José Manuel Hernández-Mogollón, University of Extremadura, Spain

Shaul Krakover, Ben Gurion University, Israel Jean Pierre Levy-Mangin, University of Quebec, Canada Tomás López-Guzmán, University of Córdoba, Spain Yasuo Ohe, Chiba University, Japón Mirko Perano, University of Salerno, Italy María de los Ángeles Plaza-Mejía, University of Huelva, Spain Nuria Porras-Bueno, University of Huelva, Spain João Albino Silva, Algarve University, Portugal

\section{Advisory Board (Spanish Members)}

César Camisón-Zornoza, Uniersity of Valencia, Spain Enrique Claver-Cortés, University of Alicante, Spain María Teresa Fernández-Alles, University of Cádiz, Spain José Luis Galán-González, University of Seville, Spain Félix Grande-Torraleja, University of Jaén, España Antonio Leal-Millán, University of Seville, Spain Inmaculada Martín-Rojo, University of Málaga, Spain Antonio Manuel Martínez-López, University of Huelva, Spain Francisco José Martínez-López, University of Huelva, Rector, Spain

Pablo A. Muñoz-Gallego, University of Salamanca, Spain
Francisco Riquel-Ligero, University of Huelva, Spain José Miguel Rodríguez-Antón, Autonomous University of Madrid, Spain

Sandra Sanchez-Cañizares, University of Cordoba, Spain Josep Francesc Valls-Giménez, ESADE, Spain

\section{Advisory Board (Other European Members)}

Paulo Aguas, University of Algarve, Portugal Gustavo Barresi, University of Messina, Italy Carlos Costa, Aveiro University, Portugal Salvatore Esposito de Falco, University of Rome "La Sapienza", Italy

Sheila Flanagan, Dublín Institute of Technology, Ireland Tania Gorcheva, Tsenov Academy of Economics, Bulgaria Tadeja Jere-Lazanski, University of Primorska, Slovenia Metin Kozak, Mugla University, Turkey Álvaro Matias, Lusiada University, Portugal Alfonso Morvillo, National Research Council, Italy Alexandru Nedelea, Stafan cel Mare University of Suceava, Romania

Claudio Nigro, University of Foggia, Italy

Angelo Presenza, University "G. D'Annunzio" of ChietiPescara, Italy

Kanes Rajah, Royal Agricultural University, United Kingdom

\section{Advisory Board (Members from the rest of the world)}

John Allee, American University of Sharjah, United Arab Emirates

Nestor Pedro Braidot, National University of La Plata, Argentina

Roberto Elias Canese, Columbia University, Rector, Paraguay

Luca Casali, Queensland University of Technology, Australia Nimit Chowdhary, Indian Institute of Tourism and Travel Management, India

Steven Chung-chi Wu, National Pingtung University of Science and Technology, Taiwán

Dianne Dredge, Southern Cross University, Australia Daniel Fesenmaier, Temple University, United States

Babu George, Alaska Pacific University, United States Dogan Gursoy, Washington State University, United States Jafar Jafari, University of Wisconsin-Stout, United States Sanggun Lee, Pai Chai University, Korea Republic of Albert Yeh Shangpao, I-SHOU University, Taiwán Pauline Sheldon, University of Hawaii, United States Germán A. Sierra-Anaya, University of Cartagena de Indias, Rector, Colombia Xiaohua Yang, University of San Francisco, United States 


\title{
STAKEHOLDER PERCEPTIONS OF TOURISM ASSETS AND SUSTAINABLE TOURISM DEVELOPMENT IN DA NANG, VIETNAM
}

\author{
Patrick J. Holladay \\ Troy University (USA) \\ pholladay@troy.edu \\ Anthony W. Dixon \\ Troy University (USA) \\ awdixon@troy.edu \\ Minh C. Nguyen \\ Duy Tan University (Vietnam) \\ minhnguyen2009@gmail.com \\ Bao Le Nguyen \\ Duy Tan University (Vietnam) \\ baole@duytan.edu.vn \\ Shuangyu Xu \\ Troy University (USA) \\ shuangyuxu@troy.edu \\ Kate Price-Howard \\ Troy University (USA) \\ pricek@troy.edu




\section{ABSTRACT}

Over the last decade, the coastal city of Da Nang, Vietnam has experienced a considerable rate of growth in its domestic and international tourist visitation. Yet, little is known about how to manage this growth into appropriate sustainable tourism for development. To better understand a way forward, 16 tourism stakeholders from the public and private sectors in Da Nang were interviewed. Specifically, questions inquired about tourism assets and sustainability. The findings in this research help to establish baseline perceptions of tourism stakeholders in Da Nang and represent a step forward in the city's interest in sustainable tourism for development.

KEYWORDS:

Vietnam; Da Nang; Sustainable Development; Stakeholder Perceptions.

ECONLIT KEYS:

Z31; Z32; Q01.

\section{INTRODUCTION}

Over the last decade, the coastal city of Da Nang, Vietnam has experienced a considerable rate of growth in their domestic and international visitors. In 2015, Da Nang welcomed 4.6 million visitors with 1.25 million international visitors with an average stay of three weeks. In 2016, the Asia and Pacific region welcomed over 308 million international visitors, a 9\% increase from 2015 (UNWTO, 2017). This represented the highest visitation for all five United Nations World Tourism Organization (UNWTO) regions, wherein Asia and the Pacific had $25 \%$ of all global visitation and $30 \%$ of the world's receipts at US $\$ 367$ billion (UNWTO, 2017). Within those numbers, South-East Asia received 113 million international arrivals and Vietnam accounted for 10 million of these for a $26 \%$ growth from the previous year. In 2017, international arrivals to Vietnam grew to nearly 11 million, an increase of $29.1 \%$ from 2016 (VNAT, 2017). Da Nang's impressive growth percentages are continuing and they are quickly climbing in the ranks of the Top 10 holiday destinations in Asia (Nguyen, 2016).

This tremendous progress necessitates the exploration of how to create a comprehensive sustainable tourism plan for $\mathrm{Da}$ Nang to prevent spontaneous 
development (c.f. Kutani et al., 2015). The question that emerges is how to undertake appropriate sustainable tourism for development and what tourism assets in the city should be developed. A well-researched investigation of Da Nang's tourism assets, including ideas for developing them, is missing from the literature. This development should take into account variables related to social, economic and environmental factors (Miller et al., 2010). In recognizing this, it becomes imperative to recruit the perceptions of tourism stakeholders in Da Nang (Jamal \& Stronza, 2009). Compounding this question of suitable tourism development, within Da Nang there are some serious liabilities in creating a valuable tourism commodity and positive tourist experience. For example, there is no true city center, some of the beaches are difficult to access, there are long distances between various tourism points-of-interest and important attractions lack signage in any languages other than Vietnamese (Nguyen \& Gallan, 2013).

Therefore, the purpose of this study is to help identify Da Nang's tourism assets in order to explore how to development the city's tourism in a sustainable manner. This was achieved by conducting interviews with key stakeholders in both the private and governmental sectors to gauge their perceptions of tourism development in Da Nang. The two main research questions focused on stakeholder perceptions of Da Nang's primary tourism assets and what is needed for sustainable tourism development in $\mathrm{Da}$ Nang.

\section{LITERATURE REVIEW - SUSTAINABLE TOURISM DEVELOPMENT AND STAKEHOLDER THEORY}

The concept of sustainable development first gained currency in the 1980's with the oft-cited definition of sustainable development, which posited it as 'development that meets the needs of the present without compromising the ability of future generations to meet their own needs' (WCED, 1987, p. 43). International standards for sustainable development cross an interconnected collection of themes found under four main categories: social, environmental, economic, and institutional (Powell, et al., 2009). For example, environmental protection (Leiserowitz, et al., 2006) and positive attitudes 
towards environmental stewardship (Hedlund-de Witt, et al., 2014) are salient to progress in sustainable development.

As a type of sustainable development, sustainable tourism development should incorporate natural resources values (Walker \& Moscardo, 2014), social responsibility (Moscardo \& Hughes, 2018), economic considerations that benefits society (Bailey \& Richardson, 2010) and support processes to maximize positive affects (Orenstein \& Shach-Pinsley, 2017). Tourism development, however, is not a solution for all community and/or economic issues (Weaver, 2006) and can have disruptive impacts on the lives of local residents (Archer, et al., 2005; Howe et al., 1997). Conversely, wellplanned tourism has potential positive impacts such as access to education, revenue generation, health services, infrastructure development, clean water, and diversified livelihoods (Manyara \& Jones, 2007).

Theoretically, this type of well-managed tourism planning will require stakeholder input (Jamal \& Stronza, 2009). Stakeholders may include tourists, host communities, private sector, government, non-governmental organizations and others (Byrd, 2007). From the perspective of this paper, stakeholders (Freeman, 1984) are at the individual scale, involved in Da Nang tourism, considered primary stakeholders and have a direct influence on tourism development because of their primary position (Miles, 2017). There is general agreement that collaboration among stakeholders will lead to more sustainable outcomes (Fyall, et al., 2012) and long-term success (Holladay \& Ormsby, 2011).

Stakeholder partnerships that include non-economic interests, participants from various disciplines, policy decisions, and capacity building are usually strong (Bramwell \& Lane, 2000). This strength stems from the involvement of stakeholders in strategic planning (Hall, 2008), which aids in the management of sustainable tourism development (Pike \& Page, 2014). Stakeholder participation will also positively influence sustainable tourism success (Waligo, et al., 2013). This success may attributed to feelings of inclusion in decision-making (Bramwell \& Lane, 2000), as well as notions of trust, learning and knowledge sharing (Holladay \& Powell, 2013). These joint management activities among stakeholders generally lead to progressive cooperation 
(Beritelli, 2011), which will influence stakeholder coordination and plan implementation (Holladay, et al., 2017).

\section{RESEARCH CONTEXT AND METHODOLOGY}

\section{1) RESEARCH CONTEXT}

Da Nang is a centrally located coastal city of Vietnam situated alongside the East Sea with Hanoi to the north and Ho Chi Minh City to the south (Figure 1) with a population of just over one million people (ESRT, 2015). Rivers, lagoons and beaches with dry, hot summers and cool, wet winters characterize the environment of Da Nang's coastal region; the rainy season takes place September through February with the heaviest rains between September and December (ESRT, 2015). Da Nang is rich in coastal resources and Forbes magazine once ranked Da Nang's foremost beach, My Khe, as one of the top six beaches in the world (Forbes, 2003). The city is popular with domestic tourists who account for a majority (77\%) of the visitation (ESRT, 2015). Da Nang tourism stakeholders are working to grow international visitation, become a transportation hub for Vietnam (via Da Nang airport) and satisfy accommodation choices for international arrivals (Nguyen \& Gallan, 2013).

At the time of this research, officials from the Ministry of Culture, Sports and Tourism informed the research team during their interview that in Da Nang there were 478 hotels, 17,671 rooms, 198 travel agencies, 1,779 tour guides, 20 restaurants and 16 shopping malls that met internationals standards, 23 direct flights and 14 charter flights from cities in China. Singapore, Hong Kong, Japan, Korea, and Malaysia. Further, in 2015 there were 2,800,000 tourist arrivals to Da Nang, which was an increase in $122 \%$ over a five-year period and an average increase of about $19 \%$ annually. 


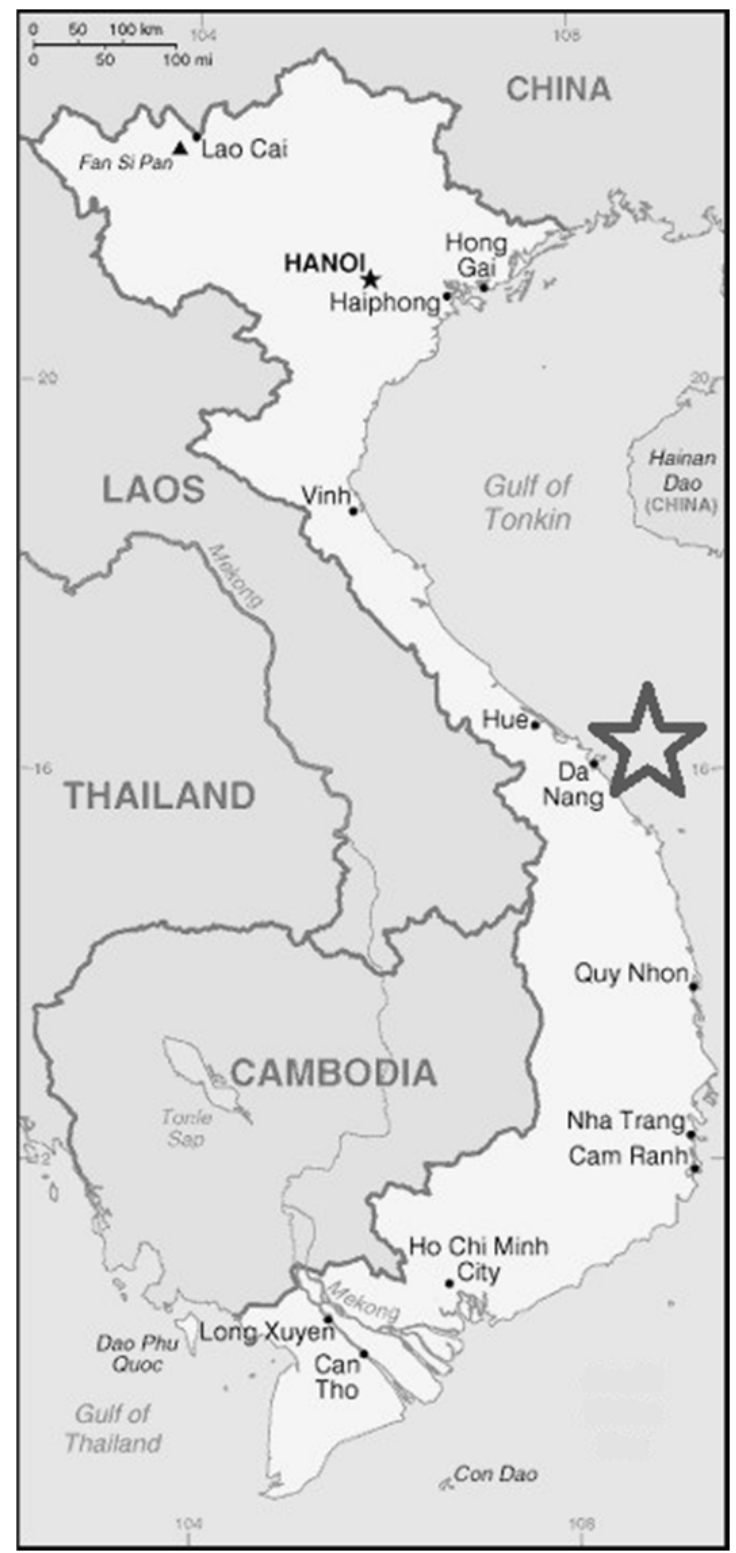

Figure 1. The location of Da Nang in Vietnam represented by the star. Source: US State Department.

\section{2) RESEARCH DESIGN AND METHODOLOGICAL APPROACH}

An inventory of tourism resources is a vital first step in tourism planning (Page \& Connell, 2006). Key tourism stakeholders perceptions of tourism assets help to identify acceptable or culturally appropriate tourism development (Page \& Connell, 2006). This inventory provides information useful for future tourism development (Pennington-Gray 
\& Carmichael, 2006). For this study, a case study approach was adopted for an in-depth study (Cox, 2015) of tourism development in Da Nang.

The case study method gathers data for evaluation of particular contexts and locations (Gillham 2010; Swanborn, 2010). A rigorous review of the literature, a formulation of rationale for the study and the creation of appropriate questions for interviews were all completed by the authors per suggestions by Yin (2014). The selection of the city of $\mathrm{Da}$ Nang as the research unit of analysis stemmed from the desire of the faculty at the Vietnamese university to understand the local tourism industry from a tourism assets standpoint.

Interviews were conducted with 16 key stakeholders from the governmental and private (Table 1). The selection was based on the network of professionals that were deemed major decision makers in the tourism industry of Da Nang. Before the interview phase, researchers used expert judgement, a review of relevant literature and previous studies they had participated in to inform the question development for the interview tool. The interviews were used to identify tourism assets in order to help identify appropriate tourism development areas. The interview script consisted of questions used to identify assets, attractions and/or tourism centerpieces and that identified stakeholder perception of what is need for sustainable tourism development in $\mathrm{Da}$ Nang.

All interviews were recorded with a digital voice recorder following permission from the interviewee(s). The interviews were then digitized and transcribed. Data were analyzed through an iterative process to identify topics and subtopics. These were then used in coding (Babbie, 2013) as a framework for more in-depth analysis of stakeholders' perceptions.

\begin{tabular}{|l|c|c|}
\hline Type & N & $\%$ of sample \\
\hline Travel agency & 4 & 25 \\
\hline Academia & 4 & 25 \\
\hline Ministry of Culture, Sport \& Tourism & 3 & 19 \\
\hline Resort & 2 & 13 \\
\hline National museum & 2 & 13 \\
\hline Destination Marketing Organization (Da Nang city) & 1 & 5 \\
\hline \multicolumn{2}{c}{ Table 1: Interviewees (n=16) by organizational type } \\
Source: Authors \\
80
\end{tabular}


Each interview was conducted in the interviewee's office or place of business and generally ranged from 30-60 minutes. With the exception of one case where three interviewees were present, there was only one interviewee per session. One research team member led the interviews, the second supplemented or followed-up and also took notes, and the Vietnamese member of the team served as a translator in cases where it was needed an interview script was used with questions specific about tourism assets and sustainability

Reliability and validity, or trustworthiness of data (Golafshani, 2003), were ensured in two ways. Comparisons among interviewees addressed "whats/hows" as a measure of validity, which aids with delineating causality (Maxwell, 2012). Second, reliability and prevention of bias were ensured through the development of the interview script, the process of coding/building themes and a thorough review of the appropriate literature (Richards \& Morse, 2007). Finally, the iterative nature of coding the interview contents assisted in the establishment of reliability.

Data were triangulated (Goffman, 1989) with document review (e.g. government and other technical reports) and direct observation in the field (Babbie, 2013). Further, unstructured and informal conversations (Turner III, 2010)-that were not recordedserved to lend additional insights that may have not been expressed during formal interviews.

\section{RESULTS}

A number of salient insights emerged from the interviewees' perceptions of Da Nang's potential tourism assets and sustainable development for tourism. Results presented here include direct quotes from the interviewees to add context and richness. The three assets that were given priority were 1) beach resort tourism, 2) Meetings, Incentives, Conventions and Events, and 3) cultural and heritage tourism (Table 2). Following these results, finding related to sustainable tourism are presented. These resolved around 1) the speed of development, 2) lack of quality human resources and $3)$ an increase in the cost of property near the coastal areas. 


\begin{tabular}{|c|c|c|}
\hline Responses & Frequency & $\%$ \\
\hline 1. Beach & 15 & 94 \\
\hline 2. $\mathrm{MICE}$ & 9 & 56 \\
\hline 3. Culture and heritage & 7 & 44 \\
\hline
\end{tabular}

Table 2: Summary of responses to tourism assets $(n=16$ interviewees)

Source: Authors

\section{1) BEACH RESORT TOURISM}

The first question asked during the interviews was what tourism assets, attractions or places should be tourism centerpieces for Da Nang. There were a number of responses with the most frequent response being "the beach". An official from the Ministry of Culture, Sports and Tourism—Vietnam's government ministry responsible for tourism-said: 'At the moment we focus on three main kinds of tourism. The first is the beach and resorts, the second is [Meetings, Incentives, Conventions, Events] MICE and shopping, and the third is culture, history and ecotourism. I think the most prominent one should be the beach tourism.'

As one resort executive said: 'I think that $70 \%$ of the customers in Vietnam or outside of Vietnam come to go to the beach.' This was echoed by the government's Destination Management Organization: 'So [the beach is] a corner stone for our tourism development'. Travel agency personnel agreed with statements like, 'Da Nang is famous for its beaches' and '[Da Nang's image], I think, is the beach....Compared with other cities in Vietnam, it is the best'.

\section{2) MEETING, INCENTIVE, CONVENTION AND EVENT TOURISM}

Related to the beach and resort tourism assets was the desire to further development Meeting, Incentive, Convention and Event Tourism. As was noted earlier, MICE is the second priority of the Ministry after the development of beach resort tourism. One member of academia said: 'MICE tourism should be put as a top priority'. 
One travel agency employee said: 'Da Nang wants to be a better tourism destination for MICE.'

Another travel agent said: 'I want to promote MICE tourism to Da Nang...I want to create markets in Singapore, Malaysia, Japan, and Korea that will come to Da Nang. We can combine MICE with the restaurants and resorts here particularly in the low season, such as September and October...to create tour incentives'. Another travel executive said, 'MICE tourism is a very suitable trend in tourism now and Da Nang has many connections because [of its geographic] location, not only in Vietnam but also in Asia...so it's very easy for direct flights'.

\section{3) CULTURAL AND HERITAGE TOURISM}

Interviewees thought that cultural and heritage tourism was important from a tourism assets perspective. As mentioned earlier, the Ministry thought aspects of culture should be prioritized third after beach resort tourism and MICE. One important cultural asset is the Cham Museum. The Cham Museum is within Da Nang proper and contains over 300 artifacts from the Champa Empire, which controlled this region from the $4^{\text {th }}-$ $15^{\text {th }}$ centuries. One government employee said: 'This museum is special in Da Nang because it is the only museum with...the artwork of the Champa people. The Champa people had a very special culture especially architecture and the temples. This museum is the best not just in Vietnam but in the world. If people want to know about the Champa people history...it's amazing'.

Another cultural aspect mentioned was spiritual tourism. As another government employee said: 'You see now many people are Buddha followers...so this can become tourism for Da Nang to focus on. This can be part of the development for the museum system. As of right now, there are 7 museums in Da Nang including the Dong Dinh museum near the Linh Ung pagoda and the Buddha museum'.

A further cultural asset in the city is the Marble Mountains, which are a series of small marble peaks within the city. As one respondent said: 'And people can go to...the Marble Mountains. They are five different marbles peaks each named after one of the five components of the universe. And at the top of the hills there are very good views of 
the ocean. And in the craft village [next to the mountains] they have very special skilled artisans that make stone carvings'.

\section{4) SUSTAINABLE DEVELOPMENT FOR TOURISM}

The next question asked if the interviewee saw any environmental and/or social impacts from tourism development in Da Nang. There was widespread emphasis on the necessity of sustainability in tourism development, although sustainable development for tourism was considered to have its challenges. For example, one respondent from a travel agency said: 'Sustainable development in Vietnam is a big problem for the Vietnamese government. The city wants more tourists to come but they also want a good environment. It is very difficult to balance from both sides.' However, a ministry official did mention that all development projects must pass an environmental impact assessment: 'Any project has to have an environmental impact form submitted to the government and an approval must be given for the project to continue. In Vietnam the laws for building are very strict.'

Some respondents indicated that they may have seen negative urban trends (e.g. pollution) but could not tie this impact specifically to tourism. For example, one museum director said: 'Up to now we are okay. We see some environmental and social impacts [from development in the city]...but not because of tourism development' and one respondent from academia said: 'Now I don't see any problems from tourism development but Han River is so polluted.'

On the other hand, there were respondents who did indicate impacts attributable to tourism development. These focused on several factors. First, there was the speed of development. For example: 'Da Nang developed tourism so fast and so it has a lot of effects' and 'it's not sustainable...Da Nang has developed hotels so fast.' The speed of development seemed to have cascading impacts. One respondent said, 'We have bad water getting to the beach from the sewer.' Another issue was traffic, particularly in the beach high season. Related to this, one interviewee from a resort said, 'Although it is better than anywhere else in Vietnam, traffic safety is still terrible.' 
Two important social issues emerged. There was a human capital issue repeated by a number of interviewees. This was the lack of quality human resources. As one respondent from a resort said: '...but when you just build hotels you don't think about the man power [needed] or the training.' A director at a travel agency said, 'I think the quality of the service now is also a problem' and another person from a travel agency said, 'so [hotels/resorts] compete to get...human resources for tourism because [Da Nang] develops so fast.' An official from the Ministry said, 'We pay attention to the human resources... But the problem is that tourism in Da Nang city is growing too quickly. It's very fast so are human resources [are not keeping pace]. Nowadays just about 55\% of the human resources are trained. And the rest are not trained yet and just doing on-the-job training'.

The price of housing and land because of hotel and resort development was considered an issue as well. As one interviewee said: 'Yes, the price of housing is increasing quickly, especially the price of land. A lot of people from the capital city Hanoi want to own the land along the beaches to build hotels.'

\section{DISCUSSION}

The intent of this research was to capture stakeholder perceptions of tourism assets and sustainable tourism development in Da Nang, Vietnam. Stakeholder input was imperative for this exploratory research, as their perspectives will have an influence on sustainable tourism planning (Miles, 2017). Collaboration, coordination and participation in this process is influential in sustainable tourism development success (Holladay, et al. 2017).

From the stakeholders' perspective the beaches, which includes resorts and coastal assets, emerged as the most important development choice. The use of local coastline and beaches is important as stakeholders recognized the abundance and value of these local natural resources. Indeed, the Ministry of Culture, Sport and Tourism indicated that the development of beach and resort tourism was their priority in Da Nang. Further, recent research indicated that Da Nang's beaches were the most popular attraction for visitors in both the domestic and international markets (ESRT, 
2015). This said, however, there should be caution with rapid beach resort development (as is the case in $\mathrm{Da} \mathrm{Nang}$ ) as this has historically led to impacts on resort quality (Smith, 1992) and coastal zone resources (Wong, 1998). A joint cooperative effort among stakeholders (Beritelli, 2011) could mitigate the speed of development. Indeed, this type of cooperation has been shown to be effective in destination management (e.g. Falk, 2017; Zemla, 2014).

The popularity of resort beach tourism makes Da Nang's beaches an asset for Meetings, Incentives, Conventions, and Events (MICE) tourism, which expressed as the second tourism priority among stakeholders behind beach resort tourism. This is an important as MICE is a valuable market to attract business travelers (Mistilis \& Dwyer, 1999). In fact, MICE tourism has been a rapidly growing tourism product in the Asia Pacific region for over 20 years (Dwyer \& Forsyth, 1997). For example, gateway cities in Australia realized higher tourism economic impacts than non-gateway cities (Mistillis \& Dwyer, 1999). Other international research has indicated the strength of MICE tourism economic impacts via direct expenditures into the local host economies (Dwyer et al., 2000; Lim \& Zhu, 2018). Capitalizing on these potential revenue streams will require partnerships among stakeholders as they develop this type of tourism (Bramwell \& Lane, 2000).

The third market considered was cultural and heritage tourism development. Evidence suggests that the development of urban cultural heritage attractions has positive effects on tourism economics and visitor satisfaction (Van Loon, et al., 2014). In fact, research on Da Nang's nearby UNESCO sites of My Son (Tuan \& Navrud, 2008) and Hoi An (Adongo et al., 2017) has demonstrated the need to understand the importance of cultural site investments and perceived social and economic benefits of locals.

There were several cultural heritage assets discussed. First, the Marble Mountains are a series of small marble peaks within the city. The Marble Mountains are considered of some salience to Da Nang's overall tourism attractiveness (Hildebrandt, 2013). During the interviews for this research the Ministry of Culture, Sport and Tourism in Da Nang identified the Marble Mountains as one of Da Nang's main tourism attractions. The mountains and caves were used as Buddhist and Hindu religious sites 
from the $7^{\text {th }}$ through $19^{\text {th }}$ centuries (ESRT, 2015). Adjacent to the Marble Mountains is the Non Nuoc Stone Village, a retail outlet specializing in marble sculptures for sale to tourists. This stone market has been criticized for being overpriced and the Marble Mountains themselves have been noted to be oversold, to have limited tourist services (e.g. food services, scheduled tours), limited interpretation and to be overcrowded in the peak tourist season (ESRT, 2015). However, this complex is the most popular attraction in the city by international travelers (ESRT, 2015). This popularity is important juxtaposed against the criticisms of this attraction. A strategic plan developed among stakeholders (Hall, 2008) should help to alleviate the negative perceptions, while increasing visitor satisfaction (Zabkar, et al., 2010).

The other major heritage attraction is the Cham Museum, which holds the largest collection of Cham art and sculpture in the world (Trinh \& Ryan, 2013). Heritage tourism and the Cham Museum were the third most discussed current tourism asset that should be developed first among all respondents in this study. This museum is popular among Vietnamese tourists who constitute the majority of visitation (Trinh \& Ryan, 2013). These visitors are generally satisfied by their museum experiences and the Cham culture aesthetic (Trinh \& Ryan, 2016). There have been some concerns about the lack of written interpretation, limited tourist services and a disconnect (no inclusive tourism package) with the My Son UNESCO site (ESRT, 2015). Further, both the Marble Mountains and the Cham Museum need to be upgraded as they do not meet international standards for tourism facilities (van Grinsven, 2013). However, the French colonial architecture of the museum building itself is considered a strength (Trinh \& Ryan, 2013).

With the continued growth of beach resort tourism there was a belief that there was a need for more local coastal protection. Beach resort tourism is a form of mass tourism that can have widespread negative social and environmental impacts (Honey \& Krantz, 2007). Resort development is generally shortsighted with a focus on quick profits, the exclusion of long-term planning, coalitions among developers and local elites that influence development, and developers may ignore environmental regulations and building codes (Honey \& Krantz, 2007). Respondents indicated a range of social and environmental concerns about rapid tourism and ancillary development around the city. 
Although many respondents said they did not see any environmental impacts, they would later identify issues that were truly environmental impacts. Anecdotally, these included water pollution, mountains destroyed with timber practices wherein the lumber was used for construction, land erosion, building and widening of roads and the loss of land for development. Since, stakeholders did recognize there were negative environmental planning it is important that the stakeholders cooperate in the mitigation of these if they hope to have long-term sustainability (e.g. Lyon, et al., 2017; Waligo, et al., 2013)

Beach resort tourism development is growing at an astonishing rate in Da Nang (Chien et al, 2012) and there was some concern from respondents about the capacity of the city's infrastructure (e.g. sewage). Moreover, social and environmental issues with resort tourism development are not new in developing countries. For example, the World Bank closed its tourism projects department arm in 1979 because projects they funded had devastating financial and environmental outcomes (Honey \& Krantz, 2007).

Respondents noted water pollution, especially in the Han River and the East Sea as an impact. Scholars have previously noted the pollution of the Han River (Dowling, 1998). Further, research has indicated that resort facilities operations are an important contributor to water pollution and originates from the water use on site (Divya \& Helen, 2015). One visitor study in Da Nang indicated that sewage waste was input near the Da Nang beach(es), creating increased health risk to those entering the ocean (ESRT, 2015). This ESRT (2015) report also noted crowding, traffic, noise, sprawl and limited service near the beaches as salient negative issues. Proactive management interventions among stakeholders (Pike \& Page, 2014) are needed in order to alleviate reactive efforts to pollution issues, such as those that follow a human-induced disaster co-located with resorts (Price-Howard \& Holladay, 2014).

The development and training (or lack of) of human capital was considered a major issue and one common in the region (Doherty et al. 2007). The supply of trained employees is not sufficient to meet demand in light of the speed of hotel and resort industry growth in the city. In developing countries, this neglect is an important concern (Liu \& Wall, 2006) included the community disconnect to economic opportunities that in turn necessitate industry training (Powell, et al., 2017). The ability to speak different 
languages, especially English, was also discussed as a deficiency in the local human resources pool. Research indicates that there is an overabundance of 3-4 star hotel rooms in Da Nang accompanied by inferior food and beverage facilities, and customer service skills (ESRT, 2015). Again, this is an indication that a stakeholder intervention, particularly from stakeholders in a position of influence, is need to address these human capital issues (Fyall, et al., 2012).

\section{CONCLUSION}

The study elicited several important insights that can be useful in future tourism sustainability and development in Da Nang. The research questions focused on what tourism assets were centerpieces in Da Nang and what is needed for sustainable tourism development in Da Nang. The most popular asset was the beach resort tourism development, followed by the Meetings, Incentives, Conventions, and Events (MICE) opportunities, and cultural and heritage sites. The negative impacts cited by several stakeholders had to do with the speed of development, concerns about quality human resources, and the soaring land and housing costs in the coastal areas.

The findings in this research helped to establish a baseline from the stakeholder's perceptions. Limitations to this research included only interviewing stakeholders with positions in tourism and not local residents. Also, these data only serve as a moment in time. The pace of development in Da Nang is high and that necessitates giving the dynamic potential for change from the time of this study until now consideration. Suggestions for further research include how to appropriately develop beach resort tourism, cultural tourism development related to gastronomical tourism and examination of impacts of urban tourism development in the face of rapid growth. There are also several limitations to this study. This qualitative study, while rich in content, can be bolstered by a quantitative study on tourism assets that lends empirical data and robustness. The number of interviewees was adequate for a qualitative study but were drawn from a mainly the governmental and private sectors. Additional interviews that measured perceptions of other stakeholders such as community members, tourism employees and visitors could be valuable. 


\section{References}

Adongo, R.; Choe, J.Y.; Han, H. Tourism in Hoi An, Vietnam: impacts, perceived benefits, community attachment and support for tourism development. International Journal of Tourism Sciences, Vol. 17, No 2, 2017, pp. 86-106.

Archer, B.; Cooper, C.; Ruhanen, L. The positive and negative impacts of tourism. In: W.F. Theodbald (ed.), Global Tourism. Amsterdam: Elsevier, 2005, pp. 79-102.

Babbie, E.R. The basics of social research. $4^{\text {th }}$ edition. Boston, Massachusetts: Cengage Learning, 2013.

Bailey, E.; Richardson, R. A new economic framework for tourism decision making. Tourism and Hospitality Research, Vol. 10, No 4, 2010, pp. 367-376.

Beritelli, P. Cooperation among prominent actors in a tourist destination. Annals of Tourism Research, Vol. 38, No 2, 2011, pp. 607-629.

Bramwell, B.; Lane, B. Tourism collaboration and partnerships: Politics, practice and sustainability. Bristol: Channel View Publications, 2000.

Chien, G.C.; Yen, I.Y.; Hoang, P.Q. Combination of theory of planned behavior and motivation: An exploratory study of potential beach-based resorts in Vietnam. Asia Pacific Journal of Tourism Research, Vol. 17, No 5, 2012, pp. 489-508.

Cox, M. A basic guide for empirical environmental social science. Ecology and Society, Vol. 20, No 1, 2015, p. 63. 
Divya, P.C.; Helen, H.M. Studies on the impact of tourism and related resorts on the water characteristics of Poovar estuary, Kerala. Asian Journal of Research in Chemistry, Vol. 9, No 11, 2016, pp. 601-607.

Doherty, L.; Klenert, A.; Manfredi, S. Expanding into Asia: The human resource challenge. Tourism and Hospitality Research, Vol. 7, No 2, 2007, pp. 109-121.

Dowling, R. Ecotourism in Southeast Asia: appropriate tourism or environmental appropriation? $1998 . \quad$ Available at: http://www.hotelonline.com/Neo/Trends/AsiaPacificJournal/July98 Ecotourism

SoutheastAsia.html [accessed 12 April 2018].

Dwyer, L.; Forsyth, P. Impacts and benefits of MICE tourism: A framework for analysis. Tourism Economics, Vol. 3, No 1, 1997, pp. 21-38.

Dwyer, L.; Mellor, R.; Mistilis, N.; Mules, T. A framework for assessing "tangible" and "intangible" impacts of events and conventions. Event Management, Vol. 6, No 3, 2000, pp. $175-189$.

European Union-Environmentally and Socially Responsible Tourism. Technical Report: Regional Tourism Product Development. 2015. Available at: http://vietnamtourism.gov.vn/esrt/FileDownload69.pdf [accessed 1 October 2018].

Falk, M. Gains from horizontal collaboration among ski areas. Tourism Management, Vol. 60, 2017, pp. 92-104.

Forbes. The world's best 2003. https://www.forbes.com/2003/07/10/cx cv 0710feat2.html [accessed 12 April 2018]. 
Fyall, A.; Garrod, B.; Wang, Y. Destination collaboration: A critical review of theoretical approaches to a multi-dimensional phenomenon. Journal of Destination Marketing \& Management, Vol. 1, No 1-2, 2012, pp. 10-26.

Gillham, B. Case Study Research Methods. New York, New York: Continuum, 2010.

Goffman, E. On fieldwork. Journal of Contemporary Ethnography, Vol. 18, No 2, 1989, pp. 123-132.

Golafshani, N. Understanding reliability and validity in qualitative research. The Qualitative Report, Vol. 8, No 4, 2003, pp. 597-606.

Hall, C.M. Tourism planning: policies, processes and relationships, 2nd ed. Harlow: Pearson Education, 2008.

Hedlund-de Witt, A.; De Boer, J.; Boersema, J.J. Exploring inner and outer worlds: A quantitative study of worldviews, environmental attitudes, and sustainable lifestyles. Journal of Environmental Psychology, Vol. 37, 2014, pp. 40-54.

Hildebrandt, A.M. Current tourism structures in Central Vietnam: need for a Destination Management Organization? Current tourism structures in Central Vietnam: need for a Destination Management Organization? 2013. Available at: http://www.tourismmaster.com/wp-content/uploads/2008/03/Master-Thesis-T. Hildebrandt-CentralVietnam.pdf [accessed 12 April 2018].

Holladay, P.J.; Ormsby, A.A. A comparative study of local perceptions of ecotourism and conservation at Five Blues Lake National Park, Belize. Journal of Ecotourism, Vol. 10, No 2, 2011, pp. 118-134. 
Holladay, P.J.; Powell, R.B. Resident perceptions of social-ecological resilience and the sustainability of community-based tourism development in the Commonwealth of Dominica. Journal of Sustainable Tourism, Vol. 21, No 8, 2013, pp. 1188-1211.

Honey, M.; Krantz, D. Global trends in coastal tourism. Washington DC: Center on Ecotourism and Sustainable Development, 2007.

Howe, J.; McMahon, E.; Propst, L. Balancing nature and commerce in gateway communities. Washington D.C.: Island Press, 1997.

Jamal, T.; Stronza, A. Collaboration theory and tourism practice in protected areas: Stakeholders, structuring and sustainability. Journal of Sustainable Tourism, Vol. 17, No 2, 2009, pp. 169-189.

Kutani, I.; Sudo, Y.; Li, Y. (2015). Energy efficiency improvement in the transport sector through transport improvement and smart community development in urban areas. 2015. Available at http://www.eria.org/RPR-FY2014-38.pdf [accessed 12 April 2018].

Leiserowitz, A.A.; Kates, R.W.; Parris, T.M. Sustainability values, attitudes, and behaviors: A review of multinational and global trends. Annual Review of Environment and Resources, Vol. 31, 2006, pp. 413-444.

Lim, C.; Zhu, L. Examining the link between meetings, incentive, exhibitions, and conventions (MICE) and tourism demand using generalized methods of moments (GMM): the case of Singapore. Journal of Travel \& Tourism Marketing, Vol. 35, No 7, 2018, pp. 846-855.

Liu, A.; Wall, G. Planning tourism employment: a developing country perspective. Tourism Management, Vol. 27, No 1, 2006, pp. 159-170. 
Lyon, A.; Hunter-Jones, P.; Warnaby, G. Are we any closer to sustainable development? Listening to active stakeholder discourses of tourism development in the Waterberg Biosphere Reserve, South Africa. Tourism Management, Vol. 61, 2017, pp. 234-247.

Manyara, G.; Jones, E. Community-based tourism enterprises development in Kenya: An exploration of their potential as avenues of poverty reduction. Journal of Sustainable Tourism, Vol. 15, No 6, 2007, pp. 628-644.

Maxwell, J.A. Qualitative research design: An interactive approach. Thousand Oaks, California: Sage Publications, 2012.

Miles, S. Stakeholder theory classification: A theoretical and empirical evaluation of definitions. Journal of Business Ethics, Vol. 142, No 3, 2017, pp. 437-459.

Miller, G.; Rathouse, K.; Scarles, C.; Holmes, K.; Tribe, J. Public understanding of sustainable tourism. Annals of Tourism Research, Vol. 37, No 3, 2010, pp. 627-645.

Mistilis, N.; Dwyer, L. Tourism gateways and regional economies: the distributional impacts of MICE. The International Journal of Tourism Research, Vol. 1, No 6, 1999, pp. 441-457.

Moscardo, G.; Hughes, K. All aboard! Strategies for engaging guests in corporate responsibility programmes. Journal of Sustainable Tourism, Vol. 26, No 7, 2018, pp. 1257-1272.

Nguyen, X. Da Nang to receive 5.51 million visitors in 2016. 2016. Available at http://hanoitimes.com.vn [accessed 21 September 2017]. 
Nguyen, C.M.; Gallan D. Marketing developing tourism markets to international tourists: Central Viet Nam as a case study. The 2nd World Research Summit for Tourism and Hospitality in Florida, December, 2013.

Orenstein, D.E.; Shach-Pinsley, D. A comparative framework for assessing sustainability initiatives at the regional scale. World Development, Vol. 98, 2017, pp. 245-256.

Page, S.; Connell, J. Tourism: A modern synthesis. Boston, Massachusetts: Cengage Learning, 2006.

Pennington-Gray, L.; Carmichael, A.B. Political-economic construction of quality tourism experiences. In G. Jennings \& N.P. Nickerson (Eds.), Quality tourism experiences. London: Elsevier, 2006, pp. 208-223.

Pike, S.; Page, S.J. Destination Marketing Organizations and destination marketing: A narrative analysis of the literature. Tourism Management, Vol. 41, 2014, pp. 202-227.

Powell, R.B.; Cuschnir, A.; Peiris, P. Overcoming governance and institutional barriers to integrated coastal zone, marine protected area, and tourism management in Sri Lanka. Coastal Management, Vol. 37, No 6, 2009, pp. 633-655.

Powell, R.B.; Green, T.F.; Holladay, P.J.; Krafte, K.E.; Duda, M.; Nguyen, M.T.; Spencer, H.; Das, P. Examining Community Resilience to Assist in Sustainable Tourism Development Planning in Dong Van Karst Plateau Geopark, Vietnam. Tourism Planning \& Development, Vol. 15, No 4, 2017, pp. 436-457.

Price-Howard, K.; Holladay, P.J. Resorts, resilience and retention after the BP Oil spill disaster of 2010. Journal of Tourism Insights, Vol. 5, No 1, 2014, pp, 2. 
Richards, L.; Morse, J.M. Readme first for a user's guide to qualitative methods. Thousand Oaks, California: Sage Publications, 2012.

Smith, R.A. Beach resort evolution: Implications for planning. Annals of Tourism Research, Vol. 19, No 2, 1992, pp. 304-322.

Swanborn, P. Case Study Research. London: Sage Publications, 2012.

Trinh, T.T.; Ryan, C. Museums, exhibits and visitor satisfaction: A study of the Cham Museum, Da Nang, Vietnam. Journal of Tourism and Cultural Change, Vol. 11, No 4, 2013, pp. 239-263.

Trinh, T.T.; Ryan, C. Heritage and cultural tourism: the role of the aesthetic when visiting Mỹ Sơn and Cham Museum, Vietnam. Current Issues in Tourism, Vol. 19, No 6, 2016, pp. 564-589.

Tuan, T.H.; Navrud, S. Capturing the benefits of preserving cultural heritage. Journal of Cultural Heritage, Vol. 9, No 3, 2008, pp. 326-337.

Turner III, D.W. Qualitative interview design: A practical guide for novice investigators. The Qualitative Report, Vol. 15, No 3, 2010, pp. 754-760.

United Nations World Tourism Organization. UNWTO Tourism Highlights, 2017 Edition. 2017. Available at: http://mkt.unwto.org/publication/unwto-tourism-highlights [accessed 12 April 2018].

Van Grinsven, G. (2013). The people who built bridges. 2013. Available at: https://www.pum.nl/sites/default/files/people who build bridges - edit 09 12.pdf [accessed 12 April 2018]. 
Van Loon, R.; Gosens, T.; Rouwendal, J. Cultural heritage and the attractiveness of cities: evidence from recreation trips. Journal of Cultural Economics, Vol. 38, No 3, 2014, pp. 253-285.

Vietnam National Administration of Tourism. Da Nang sees significant growth in foreign visitors in 2017.2017 .2 Available http://vietnamtourism.gov.vn/english/index.php/items/12422 [accessed 12 April 2018].

Waligo, V.M.; Clarke, J.; Hawkins, R. Implementing sustainable tourism: A multistakeholder involvement management framework. Tourism Management, Vol. 36, 2013, pp. 342-353.

Walker, K.; Moscardo, G. Encouraging sustainability beyond the tourist experience: ecotourism, interpretation and values. Journal of Sustainable Tourism, Vol. 22, No 8, 2014, pp. $1175-1196$.

Weaver, D.B. Sustainable tourism: Theory and practice. New York: Routledge, 2006.

Wong, P.P. Coastal tourism development in Southeast Asia: relevance and lessons for coastal zone management. Ocean \& Coastal Management, Vol. 38, No 2, 1998, pp. 89109.

World Commission on Environment and Development. Report of the World Commission on Environment and Development: Our Common Future. United Nations, 1998.

Yin, R.K. Case study research: design and methods, $4^{\text {th }}$ edition. Thousand Oaks, California: Sage, 2014.

Žabkar, V.; Brenčič, M.M.; Dmitrović, T. Modelling perceived quality, visitor satisfaction and behavioural intentions at the destination level. Tourism Management, Vol. 31, No 4, 2010, pp. 537-546. 
Żemła, M. Inter-destination cooperation: Forms, facilitators and inhibitors-The case of Poland. Journal of Destination Marketing \& Management, Vol. 3, No 4, 2014, pp. 241252.

Article info: Received 04/05/18. Accepted 04/10/18. Refereed anonymously. 